\title{
SPIDER COMMUNITIES AFFECTED BY EXCLUSION NETS
}

\author{
PAJAČ ŽIVKOVIĆ, I. ${ }^{1}$ - LEMIC, D. $.^{1 *}-$ SAMU, F. ${ }^{2}-$ KOS, ${ }^{3}{ }^{3}$ - BARIĆ, B. ${ }^{1}$ \\ ${ }^{1}$ Department of Agricultural Zoology, Faculty of Agriculture, University of Zagreb \\ Svetošimunska 25, 10000 Zagreb, Croatia \\ ${ }^{2}$ Plant Protection Institute, Centre for Agricultural Research, Hungarian Academy of Science \\ H-1525 Budapest, Hungary \\ ${ }^{3}$ Department of Ecology, Agronomy and Aquaculture, University of Zadar, Zadar, Croatia \\ *Corresponding author \\ e-mail: dlemic@agr.hr; phone: +385-1-239-3649
}

(Received $30^{\text {th }}$ Sep 2018; accepted $22^{\text {nd }}$ Nov 2018)

\begin{abstract}
Spiders are one of the most abundant natural enemies in apple orchards and have an important role in the biological control of harmful arthropods. Recently, coloured shade nets were introduced into management practices to improve the utilization of solar radiation by fruit trees and to exclude pest species. While the coloured netting in apple orchards had a positive effect on fruits, the secondary aim of our research was to analyse the influence the nets had on spider diversity and species composition. In this study we sampled the ground dwelling spider assemblage by pitfall trapping and identified spiders to species. Traps were placed under trees covered by four types of exclusion photo selective nets and uncovered (control) trees in an untreated experimental plot of an apple orchard. In total 456 individuals belonging to 13 families and 26 species of spiders were collected. Two wolf spider (Araneae, Lycosidae) species dominated the assemblages; Trochosa robusta (Simon, 1876) and Hogna radiata (Latreille, 1819) comprised $45 \%$ of the total adult catch. Spider abundance showed a declining trend over season in all treatments. Most importantly, there was no difference either between the abundance, species richness or the species composition of spiders in the treatments. The study strongly indicates that insect exclusion nets have no negative effect on ground dwelling spider assemblages.
\end{abstract}

Keywords: Araneae, shade nets, apple orchard, Trochosa robusta, Hogna radiata

\section{Introduction}

For sustainable agricultural systems, self-regulation of insect pests by predatory arthropods is considered to be crucial in preventing insect pest outbreaks (Kromp, 1999). Spiders, as one of the most abundant natural enemies in apple orchards, have an important role in the natural control of harmful arthropods in pome production (Pekár and Kocourek, 2004). However, the intensity of the management practices can seriously limit the positive effect of spiders and other beneficial organisms on pests that they control. Intensively managed agricultural areas are treated on a regular basis by different agrochemicals, but even a small number of synthetic, broad- spectrum insecticide applications can severely reduce spider abundance and diversity in apple orchards and the time required for recovery may be lengthy (Miliczky et al., 2000). While in low-intensity apple production (e.g. self-sustainable ecological systems) spiders play a key role in the regulation of lepidopteran pests (Nyffeler and Benz, 1987), in intensive apple production spiders can regulate only some secondary pest populations below economically damaging levels, but usually cannot efficiently regulate the primary, key pest populations (e.g. codling moth (Cydia pomonella L.)) (Cross et al., 2015).

Integrated apple production is based on the application of environmentally and toxicologically acceptable treatments with an emphasis on the use of ecologically 
favourable control methods. The preservation of natural enemies of secondary pests is a crucial part of successful integrated pest management (IPM) and all affective control methods should only be minimally harmful or completely harmless to these important natural enemies (Cross et al., 2015). By reducing the insecticide applications diversity and species composition of ground dwelling arthropods can be improved (Cole et al., 2005). Like some other beneficial insects (e.g. ground beetles), spiders serve as bio-indicators of the stability of sustainable agro-ecosystems (Dennis et al., 1997, 1998 cit. Cole et al., 2005). The diversity and species composition of European epigeic spider fauna was intensively studied in IPM apple production orchards and up to 37 species were found (Bogya and Markó, 1999; Bogya et al., 1999; Pekár, 1999).

Management intensity at other scales also influences natural enemy populations. Batáry et al. (2012) studied the effects of landscape scale management intensity and agroecosystem type on the biodiversity of spiders and other arthropods. They found that management intensity affected several functional groups positively, including hunting spiders, and lower landscape scale management intensity also increased species richness spiders. The diversity of spiders is also affected by habitat heterogeneity. It is known that in areas of ecological infrastructure (e.g. flowering field margins and border strips, hedges, ditches and stone walls) a positive effect on the arthropod complex is found (Franin, 2016) as they enhance the diversity of the fauna in IPM systems (Boller et al., 2004). A study by Bousekou and Kherbouche-Abrus (2017) demonstrated that there are diverse and stable spider communities at the edges of wheat crops that could be related to the diversified flora offering different microhabitats and ecological niches to cater to the varied habitat requirement of multiple spider species (Bousekou and Kherbouche-Abrus, 2017).

Smaller scale alternative management practices can also greatly improve the efficiency of biological control. In recent times a new approach used involves the use of coloured shade nets (ColorNets) that improve the utilization of solar radiation by fruit trees (Shahak et al., 2004). The coloured netting in apple orchard has a positive effects on flowering, fruit-set, fruit size, colour and internal quality, in addition to non-specific reduction of water stress, superficial damage and sunburn (Shahak et al., 2004). Such systems usually also include anti-hail nets and these can inadvertently act as insect exclusion netting systems too. The beneficial effects of netting structures against Lepidoptera species (e.g. codling moth) has been proven in several studies (Tasin et al., 2008; Sauphanor et al., 2012; Pajač et al., 2016). Dedicated exclusion nets are designed to control a single pest species, although other pests might also be controlled, depending on the mesh size used (Chouinard et al., 2017). Since the netting structures form a physical barrier to the entry of insect pests, it potentially also serves as a barrier to beneficial insects and allied forms such as spiders that inhabit agroecosystems (Pajač et al., 2016). The main objective of the present research is to analyse the possible effects of the exclusion nets on spider diversity and species composition in an IPM apple orchard.

\section{Materials and methods}

\section{Study area}

The study was conducted during the vegetation period of 2015 in an apple orchard, situated in the northwest part of Croatia $\left(46^{\circ} 9^{\prime} 47^{\prime \prime} \mathrm{N}, 15^{\circ} 52^{\prime} 52^{\prime \prime} \mathrm{E}\right)$. This area is characterized by a continental-humid climate of warm, rainy summers and cold winters (Penzar and Penzar, 2000). The elevation is $282 \mathrm{~m}$, the average annual precipitation is 
$850 \mathrm{~mm}$ and the average annual temperature is $11^{\circ} \mathrm{C}$ (HMD, 2017). The soil in the research area is typical pseudogley (IUSS Working Group WRB, 2015). In the plantation of $3600 \mathrm{~m}^{2}$ apple cultivars of 'Braeburn', 'Idared', 'Golden Delicious', 'Granny Smith' and 'Jonagold' were grown following standard IPM practices. IPM in practice, involves using several control measures based on knowledge of the crop, pests and associated natural enemies to avoid crop loss and minimize harmful effects on the environment. In this apple orchard IPM involves: identifying pests; identifying the natural enemies of pests' monitoring both and tolerating higher levels of pests; using a treatment threshold to decide when control is needed; managing weeds by mulching treatments between rows several times in the season; and follow-up to see how well control measures work and if further action is needed. Experiments took place in the central part of the orchard planted with cv. 'Braeburn'. During the research period, insecticide treatments were not applied to the experimental site. The orchard was surrounded by agricultural fields (arable lands and grasslands).

\section{Experimental design}

Four types of exclusion photo selective nets (Agritenax nets and Stop Drosophila Normal net) were placed randomly in three replicates in the experimental area of the orchard (Fig. 1). The size of a single net was $6 \times 6 \mathrm{~m}$. Three rows of trees served as spatial replicates of the treatment. In each row there were four randomly selected neighbouring apple trees completely covered with nets and an uncovered control. Pitfall traps were placed beneath each experimental tree (distance between tress were $10 \mathrm{~m}$ ), in the case of netted trees, inside the enclosed area. Agritenax nets (Tenax S.r.l., Italy) were used with a set mesh size of $2.4 \times 4.8 \mathrm{~mm}$ but in different colours (white, red and yellow). Stop Drosophila Normal net (Artes Politecnica, Italy) had a pearl colour and a $0.9 \times 1 \mathrm{~mm}$ mesh size. While exclusion nets are designed to control a pest species, no pest should be under the nets at the beginning of investigation period. So, before setting up nets in May 2015, existing arthropod fauna on apple trees was eliminated by applying neonicotinoid insecticide thiacloprid (Calypso ${ }^{\circledR} 480$ SC, Bayer CropScience). Exclusion nets were set up at petal fall and were removed after the harvest of apple fruits as is standard practice.

\section{Spider sampling}

Spiders were collected during the summer and autumn (from July $1^{\text {st }}$ until October $\left.15^{\text {th }}, 2015\right)$. Pitfalls were polythene pots $(\varnothing=10 \mathrm{~cm}$ wide and $\mathrm{h}=20 \mathrm{~cm})$ half filled with salted water ( $20 \%$ solution) for preservation. Fifteen pitfall traps (twelve under covered and three under uncovered trees) were set in the IPM orchard. Traps were inspected on a weekly basis (from week 28 to week 42) and spiders were transferred to $70 \%$ ethanol pending identification to species.

\section{Data analysis}

A preliminary analysis of adult abundance and species richness data included inspection of data distribution and variation by replicate and date. Overall catches were very similar in all three replicates, but spider abundance showed a marked seasonal decline in all treatments over the sampling dates. Since spider catches were relatively low per pitfall per sampling date, the final data analysis of abundance and richness was carried out on data pooled across replicates but analysed by date. Abundance data were 
$\log$ transformed and then analysed using a linear model that included treatment as fixed factor and sampling date as continuous covariate. The same model structure was applied for species richness in a generalized linear model with Poisson distribution and log link function. To understand whether species composition was affected by the treatments we applied detrended correspondence analysis (DCA). For this ordination analysis data was pooled across sampling dates but was kept separate by replicate.

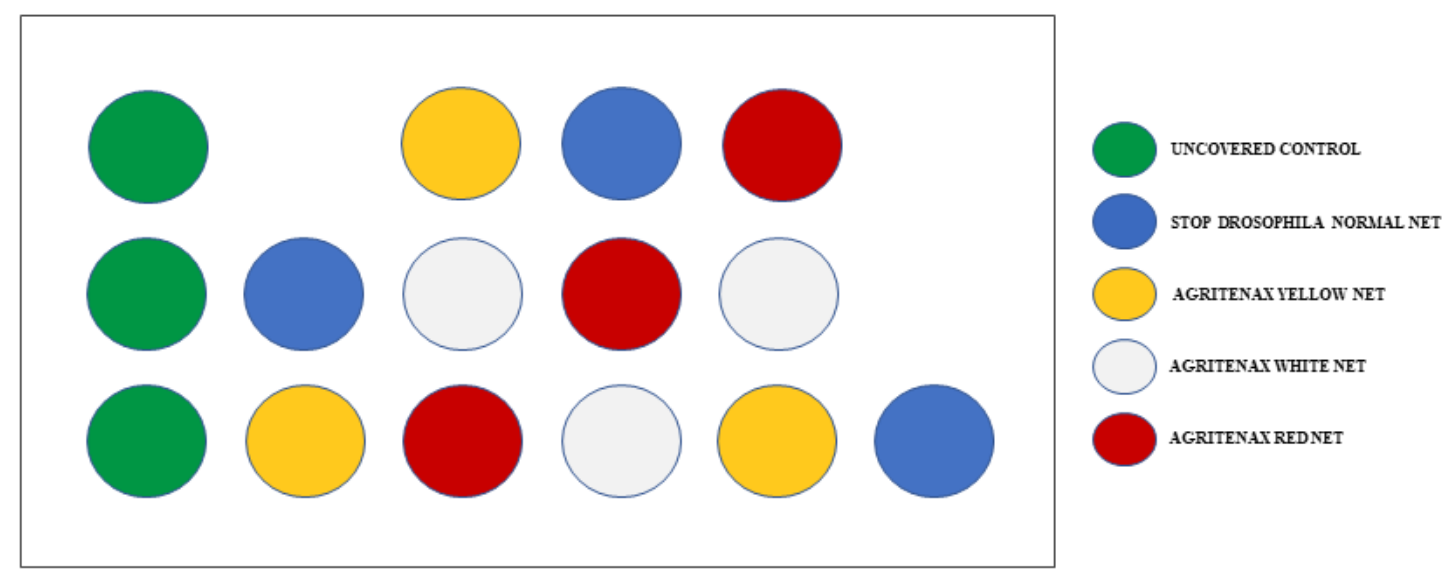

Figure 1. Schematic representation of experimental design

\section{Results and discussion}

Approximatley 456 individuals belonging to 26 species and 13 families of spiders were collected (Table 1). Spider abundance showed a natural declining trend over season (Fig. 2) (effect of date: $\mathrm{F}=43.83$, d.f. $=1,65, \mathrm{P}<0.0001$ ); however, the rate of decline was not significantly different across treatments (effect of date $\mathrm{x}$ treatment: $\mathrm{F}=1.01$, d.f. $=4,65, \mathrm{P}=0.41)$.

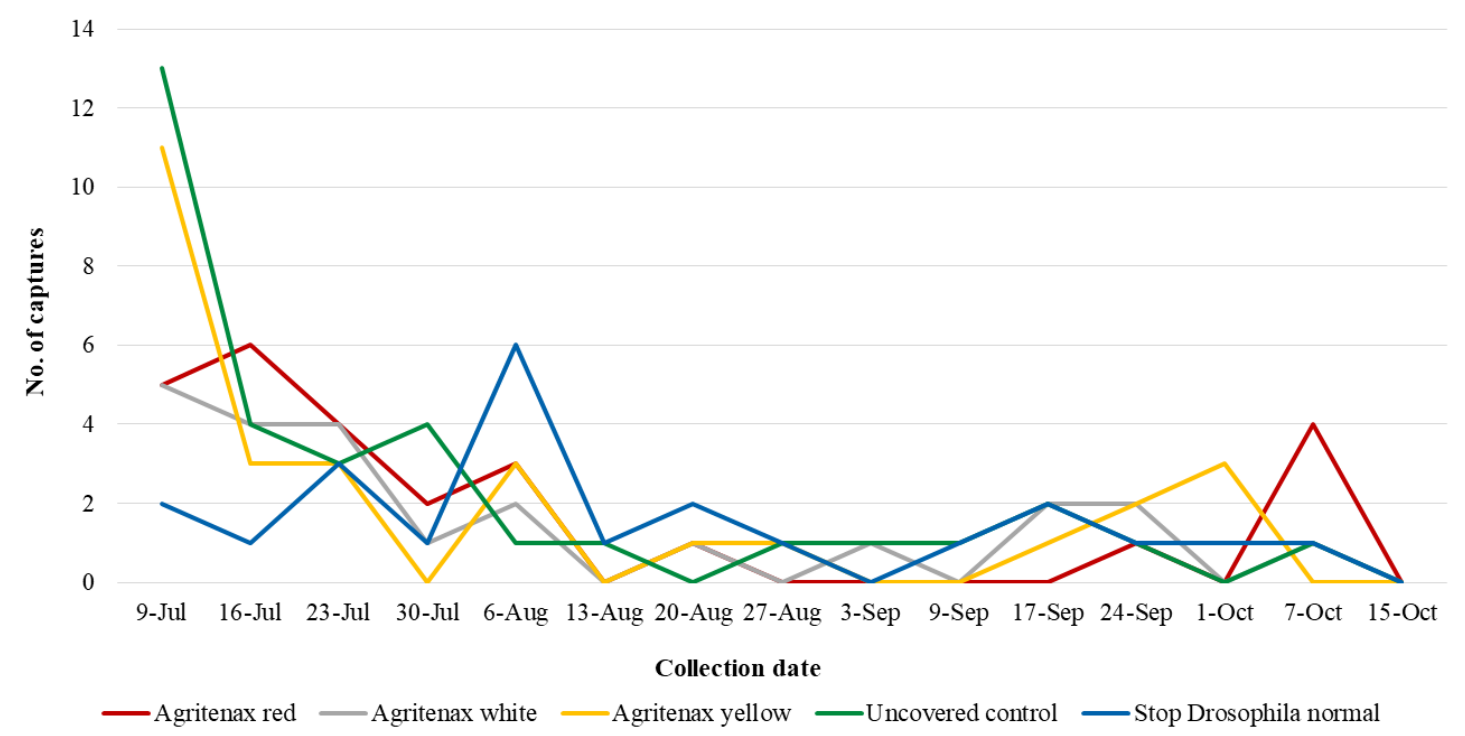

Figure 2. Seasonal distribution of spider species during 2015 in IPM apple orchard under different exclusion nets and on uncovered control 
Table 1. The list of spider species and captures in IPM apple orchard

\begin{tabular}{|c|c|c|c|c|c|c|}
\hline Family & $\begin{array}{c}\text { Species } \\
\end{array}$ & A.w.* & A.r. & S.D.n. & A.y. & U.c. \\
\hline \multirow{2}{*}{ Agelenidae } & Agelena labyrinthica (Clerck, 1757) & & & & 1 & \\
\hline & Allagelena gracilens (Koch, 1841) & & & 1 & & \\
\hline Dysderidae & Dysdera erythrina (Walckenaer, 1802) & & 2 & 1 & 1 & 2 \\
\hline \multirow{4}{*}{ Gnaphosidae } & Drassodes lapidosus (Walckenaer, 1802) & 1 & & & & \\
\hline & Drassyllus pumilus (Koch, 1839) & & & & 1 & 1 \\
\hline & Zelotes aurantiacus (Miller, 1967) & & 1 & 1 & & \\
\hline & Zelotes longipes (Koch, 1866) & 3 & & 2 & 2 & 4 \\
\hline Hahniidae & Cryphoeca silvicola (Koch, 1834) & 2 & 1 & & 1 & 2 \\
\hline \multirow{4}{*}{ Linyphiidae } & Centromerus sylvaticus (Blackwall, 1841) & & & 1 & & \\
\hline & Diplostyla concolor (Wider, 1834) & & 1 & 2 & & \\
\hline & Stemonyphantes lineatus (Linnaeus, 1758) & & & 1 & & \\
\hline & Tenuiphantes flavipes (Blackwall, 1854) & 1 & & & & \\
\hline Liocranidae & Liocranoeca striata (Kulczynski, 1882) & 2 & & & 1 & 1 \\
\hline \multirow{7}{*}{ Lycosidae } & Alopecosa pulverulenta (Clerck, 1757) & & 1 & & & 1 \\
\hline & Hogna radiata (Latreille, 1819) & 2 & 10 & 3 & 3 & 11 \\
\hline & Pardosa agrestis (Westring, 1861) & & 1 & & 1 & 1 \\
\hline & Pardosa hortensis (Thorell, 1872) & & 2 & & 1 & \\
\hline & Pardosa palustris (Linnaeus, 1758) & & & & & 2 \\
\hline & Trochosa robusta (Simon, 1876) & 6 & 5 & 8 & 6 & 5 \\
\hline & Xerolycosa miniata (Koch, 1834) & & & & 1 & \\
\hline Philodromidae & Philodromus cespitum (Walckenaer, 1802) & & & & & 1 \\
\hline Phrurolithidae & Phrurolithus festivus (Koch, 1835) & 1 & & 1 & & 1 \\
\hline Tetragnathidae & Pachygnatha degeeri (Sundevall, 1830) & 3 & & 1 & 5 & \\
\hline Theridiidae & Enoplognatha thoracica (Hahn, 1833) & & 1 & & 1 & \\
\hline Thomisidae & Zodarion rubidum (Simon, 1914) & 1 & & & 3 & \\
\hline Zodariidae & Zodarion rubidum (Simon, 1914) & & 1 & 1 & & \\
\hline
\end{tabular}

*Net type: A.w. - Agritenax white; A.r. - Agritenax red; S.D.N. - Stop Drosophila normal; A.y. Agritenax yellow; U.c. - Uncovered control

There was no difference between the abundance of spiders between treatments (effect of treatment: $\mathrm{F}=1.23$, d.f. $=4,65, \mathrm{P}=0.31$; Fig. $3 a$ ) which indicates that netting structures did not have a negative effect on spider communities. A contrast analysis that compared all net treatments with the control (contrast effect: $\mathrm{F}=3.08$, d.f. $=1,65$, $\mathrm{P}=0.084$ ) showed that there was a tendency for net treatments to harbour more spiders than the un-netted control. Since the exclusion nets can change environmental variables (e.g. temperature, humidity, light and etc.) (Brkljača et al., 2016; Fruk et al., 2016) it is evident that these changes also positively affected spider fauna and could possible improve the habitat requirements for spiders.

When onsidering species richness, two wolf spider (Araneae, Lycosidae) species Trochosa robusta (Simon, 1876) and Hogna radiata (Latreille, 1819) comprised $45 \%$ of the total adult catch, and these were the only two species that were found in all treatments. With the exception of the red net treatment, all other treatments included 2-3 unique species, mostly unique species that were recorded from one treatment only 
(Table 1). Despite of variation in the low frequency species, the number of species recorded in the treatments fell within the narrow range of 10-14 species. The Poisson model indicated that there was no effect of the applied nets on species richness (effect of treatment: $\chi^{2}=0.18$; d.f. $=1 ; \mathrm{P}=0.99 ;$ Fig. $3 b$ ).
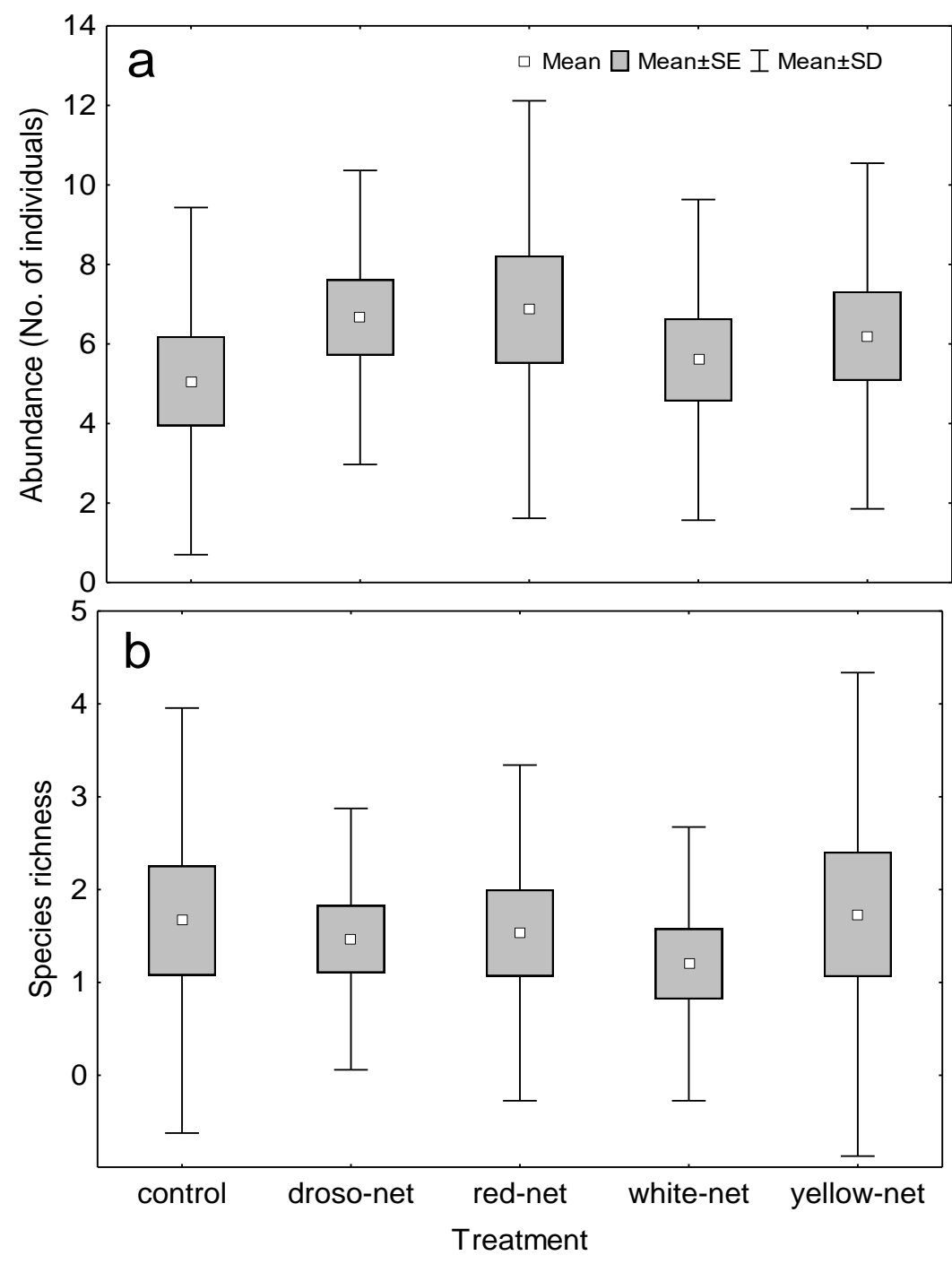

Figure 3. Abundance (a) and species richness (b) of spiders per treatment (number of individuals and species caught, respectively)

Ordination analysis was used to visualise how net treatments influenced spider species composition and assemblages. The first two axes of the applied DCA only cumulatively explained $27 \%$ of the total variation in the data (Eigenvalues of axes 1 and 2 , respectively: $0.46,0.33$ ). The ordination plot indicated that there was no separation either by treatment or by the three planting rows (replicates), in which the replicates were placed (Fig. 4).

The composition and diversity of the species recorded corresponded with similar investigations of the spider fauna in apple orchards (Bogya and Markó, 1999), as the assemblage was dominated by species from the Lycosidae and Gnaphosidae families. These predominantly ground dwelling species can have an important synergistic effect 
on canopy dwelling natural enemies, as they may prey on dislodged and migrating pests (Dainese et al., 2017). By implementing netting structures as a relatively new mechanical and environmentally friendly method into agricultural management practices we can improve the microclimate conditions for the development of spiders (e.g. important pest species predators) that can help us in regulating the populations of harmful insects in fruit production. This work was the first of its kind in Croatia investigating spider diversity in an agroecological system will serve us as important baseline information for further future research.

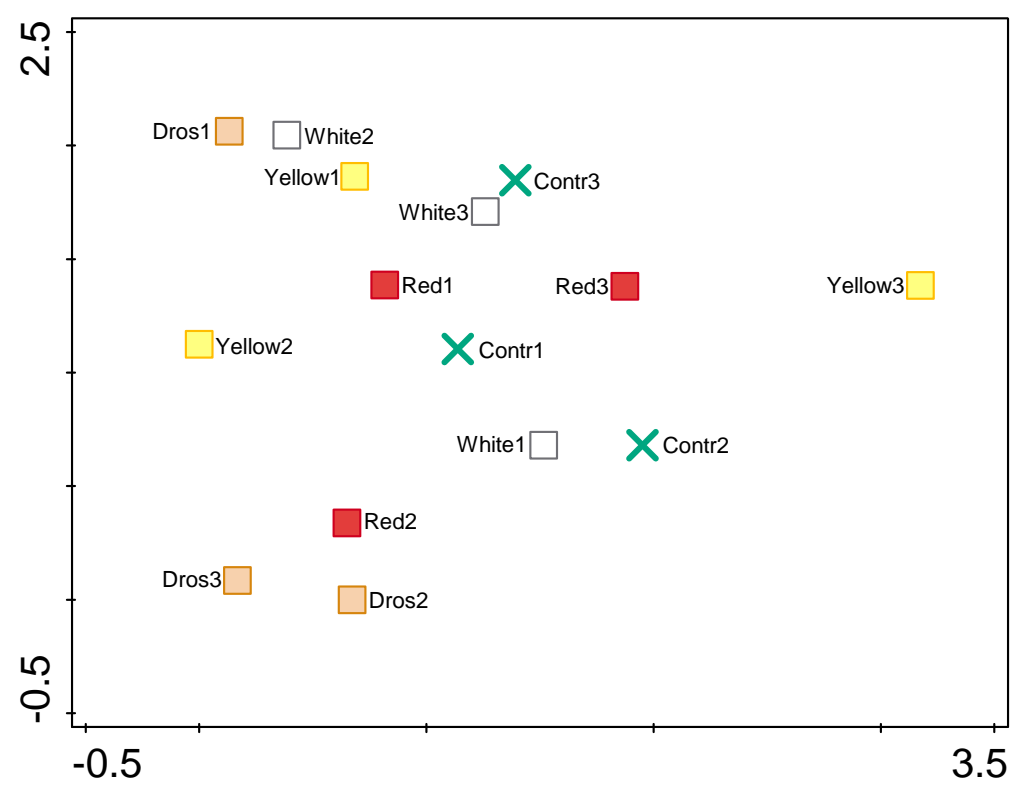

Figure 4. DCA ordination plot of spider assemblages a individual netted and control trees over the whole sampling period

The study showed that insect exclusion nets had no negative effect on beneficial spider assemblages and there was even a tendency for nets to promote their abundance, indicating that netting systems favour spider species that inhabit orchards. Considering that this alternative, environmentally friendly management approach excludes pest species and at the same time has no negative effect on the natural enemy complex, the present study provides data to support the ongoing use of pest exclusion netting in apple orchard production systems.

\section{Conclusions}

Spiders have not received much attention by researchers in Croatia, despite their ability to be used as bioindicators in agricultural systems. In this study we demonstrated the diversity of spider community assemblages from apple orchards in northwest Croatia, where 456 individuals belonging to 26 species and 13 families of spiders were collected. There was no difference between the abundance of spiders between treatments which indicated that the exclusion nets favour species composition and richness and their implementation into the practice can possibly improve the agricultural habitat for these beneficial species in the production of apples. 
Acknowledgements. This experiment was made in the frame of research project aimed to develop automatic system for detection pest and beneficial insect populations living in above ground biotypes (LIFE13 ENV/HU/001092). The research was done on the experimental plot of research project aimed to increase the fruit quality due to the effects of differently coloured photo selective anti-hail nets (LIFE13 ENV/HR/000580) in orchards. The authors would like to thank family Fruk which owns an orchard and Project Coordinator Tomislav Jemrić who allowed experiment to be carried out. Authors thank Dr Katarina Mikac for comments and English editing that significantly improved the manuscript.

\section{REFERENCES}

[1] Batáry, P., Holzschuh, A., Orci, K. M., Samu, F., Tscharntke, T. (2012): Responses of plant, insect and spider biodiversity to local and landscape scale management in cereal crops and grasslands. - Agriculture, Ecosystems \& Environment 146(1): 130-136.

[2] Bogya, S., Markó, V. (1999): Effect of pest management systems on ground-dwelling spider assemblages in an apple orchard in Hungary. - Agriculture, Ecosystems \& Environment 73: 7-18.

[3] Bogya, S., Markó, V., Szinetár, Cs. (1999): Comparison of pome fruit orchard inhabiting spider assemblages at different geographical scales. - Agricultural and Forest Entomology 1: 261-269.

[4] Boller, E. F., Avilla, J., Joerg, E., Malavolta, C., Wijnands, F. G., Esbjerg, P. (2004): Integrated Production: Principles and Technical Guidelines. 3rd edition. - IOBC/WPRS Bulletin 27(2): 1-12.

[5] Bouseksou, S., Kherbouche-Abrous, O. (2017): Accessing on biodiversity of Aranea (Arachnida, Arthropoda) in wheat field at Mitidja region (Algeria). - Proceedings of 52nd Croatian \& 12th International Symposium on Agriculture, Dubrovnik, Croatia, pp. 45-50.

[6] Brkljača, M., Rumora, J., Vuković, M., Jemrić, T. (2016): The Effect of photoselective nets on fruit quality of apple cv. 'Cripps Pink'. - Agric. Conspec. Sci. 2: 87-90.

[7] Chouinard, G., Veilleux, J., Pelletier, F., Larose, M., Philion, V., Cormier, D. (2017): Impact of exclusion netting row covers on arthropod presence and crop damage to 'Honeycrisp' apple trees in North America: A five-year study. - Crop Protection 98: 248254.

[8] Cole, L. J., McCracken, D. I., Downie, I. S., Dennis, P., Foster, G. N., Waterhouse, A., Murphy, K. J., Griffen, A. L., Kennedy, M. P. (2005): Comparing the effects of farming practices on ground beetle (Coleoptera: Carabidae) and spider (Araneae) assemblages on Scottish farmland. - Biodiversity \& Conservation 14: 441-460.

[9] Cross, J., Fountain, M., Markó, V., Nagy, C. (2015): Arthropod ecosystem services in apple orchards and their economic benefits. - Ecological Entomology 40: 82-96.

[10] Dainese, M., Schneider, G., Krauss, J., Steffan-Dewenter, I. (2017): Complementarity among natural enemies enhances pest suppression. - Scientific Reports 7: 8172.

[11] Franin, K. (2016): True bugs fauna (Insecta: Heteroptera) in ecological infrastructure of vineyard. - Doctoral Thesis, University of Zagreb, Faculty of Agriculture.

[12] Fruk, G., Fruk, M., Vuković, M., Buhin, J., Jatoi, M. A., Jemrić, T. (2016): Colouration of apple cv. 'Braeburn' grown under anti-hail nets in Croatia. - Acta Horticul. Regiotec. 19: $1-4$.

[13] HMD (Croatian Meteorological Society) (2017): http://www.meteohmd.hr/hr/aktualnosti/meteoroloska-postaja-krapina,103.html.

Accessed on 15. 09. 2017.

[14] IUSS Working Group WRB. (2015): World Reference Base for Soil Resources 2014, update 2015. International Soil Classification System for Naming Soils and Creating Legends for Soil Maps. - World Soil Resources Reports No. 106. FAO, Rome. 
[15] Kromp, B. (1999): Carabid beetles in sustainable agriculture: a review on pest control efficacy, cultivation impacts and enhancement. - Agriculture, Ecosystems and Environment 74: 187-228.

[16] Miliczky, E. R., Calkins, C. O., Horton, D. R. (2000): Spider abundance and diversity in apple orchards under three insect pest management programs in Washington State, U.S.A. - Agricultural and Forest Entomology 2: 203-215.

[17] Nyffeler, M., Benz, G. (1987): Spiders in natural pest control: a review. - Journal of Applied Entomology 103: 321-339.

[18] Pajač Živković, I., Jemrić, T., Fruk, M., Buhin, J., Barić, B. (2016): Influence of different netting structures on codling moth and apple fruit damages in Northwest Croatia. Agriculturae Conspectus Scientificus 81(2): 99-102.

[19] Pekár, S., Kocourek, F. (2004): Spiders (Araneae) in the biological and integrated pest management of apple in the Czech Republic. - JEN 128(8): 561-566.

[20] Pekár, S. (1999): Side-effect of integrated pest management and conventional spraying on the composition of epigeic spiders and harvestmen in an apple orchard (Araneae, Opiliones). - Journal of Applied Entomology 123: 115-120.

[21] Penzar, I., Penzar, B. (2000): Agrometeorologija. - Školska knjiga, Zagreb (in Croatian).

[22] Sauphanor, B., Severac, G., Maugin, S., Toubon, J. F., Capowiez, Y. (2012): Exclusion netting may alter reproduction of the codling moth (Cydia pomonella) and prevent associated fruit damage to apple orchards. - Entomologia Experimentalis et Applicata 145: 134-142.

[23] Shahak, Y., Gussakovsky, E. E., Cohen, Y., Lurie, S., Stern, R., Kfir, S., Naor, A., Atzmon, I., Doron, I., Greenblat-Avron, Y. (2004): A new approach for light manipulation in fruit trees. - Acta Horticulturae 636: 609-616.

[24] Tasin, M., Demaria, D., Ryne, C., Cesano, A., Galliano, A., Anfora, G., Ioriatti, C., Alma, A. (2008): Effect of anti-hail nets on Cydia pomonella behavior in apple orchards. Entomologia Experimentalis et Applicata 129(1): 32-36. 